\title{
Europe 1992:
}

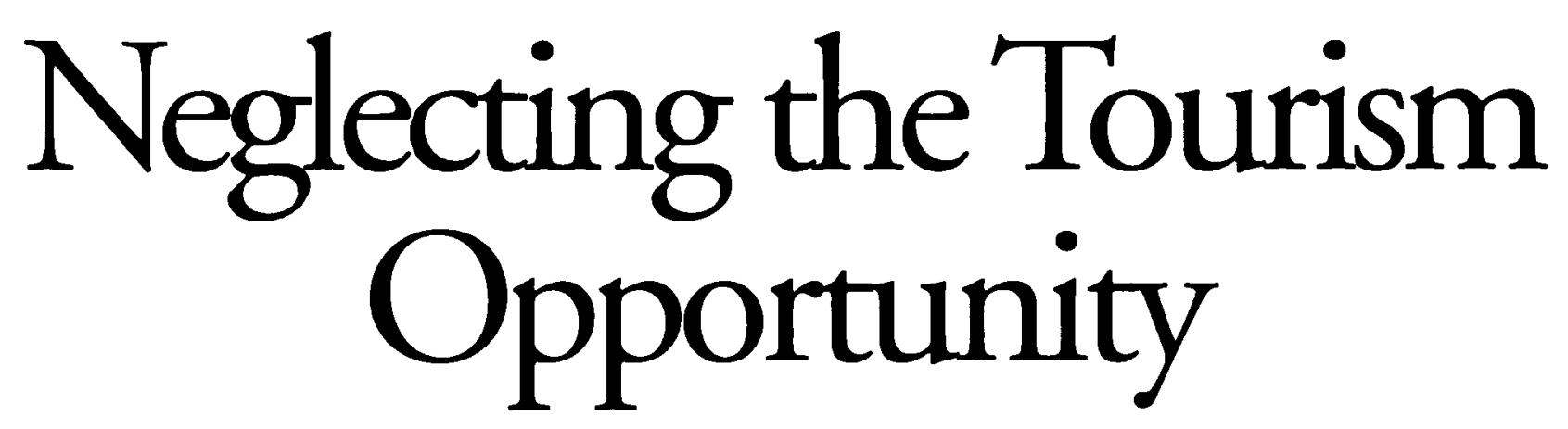

Tourism has largely been overlooked in the effort to combine the 12 members of the European Community into a single market. But the further development of European tourism is too important to leave to individual efforts.

\section{BY PETER ÅKERHIELM, CHEKITAN S. DEV, AND MALCOLM A. NODEN}

$\mathrm{T}$

Tourism has a substantial impact on the economies of the 12 member states in the European Community. It represents 5.5 percent of the EC's gross domestic product and directly employs 7.5 million persons. While a substantial portion of travel to European Community nations arises within Europe, nearly 18 percent of the travelers in 1985 came from other parts of the world, chiefly North America. ${ }^{1}$ In 1988, the flow of international tourists in Europe represented a turnover of $\$ 195$ billion, or 7 percent of the world trade in goods and services. ${ }^{2}$

In spite of its economic importance, tourism seems to have a low priority ranking in the many issues the $\mathrm{EC}$ must tackle

${ }^{1}$ Travel and Tourism Analyst, June 1987.

2 Europe, Wednesday, November 1, 1989 (World Travel Organization Statistics). before the end of 1992. The European Commission that is charged with creating a unified market after 1992 has done little to develop a tourism policy. Although it has its own commissioner, the Directorate General for Tourism and Commerce has a modest budget and a relatively small staff. In this article, we will discuss the potential and role of the European Commission in developing tourism in the European Community and, by extension, throughout all of Europe. We believe the Commission should be more aggressively involved in creating a unified tourism policy.

(c) 2003, CORNELL UNIVERSITY. This article previously appeared, in a somewhat different form, in the May 1990 issue of Cornell Quarterly (pp. 104-111). 


\section{Fundamental Changes}

There is no question that tourism will be affected by many of the basic changes that will come about in the 1992 reorganization. Tourism will be given a substantial boost by the introduction of EC passports, airline deregulation, the removal of physical barriers, and by the free movement of labor and capital and harmonization of the value-added tax.

New tourism patterns will be mostly a byproduct of these changes, however. Tourism policy lacks an overall framework. As yet, it is far from clear how active the Commission will be in standardizing, harmonizing, or promoting tourism. Currently, the EC policy on tourism is not developed enough to serve as a base for organizational strategic planning. Consequently, for hotel companies, restaurant chains, tour operators, travel agencies, and airlines, it may be a frustrating task to plan for 1992 and beyond. Many corporations and other organizations still have a hesitant approach toward the completion of the Common Market, especially if measured in cross-border activities. Not that 1992 isn't the talk of the town in our industry, but there is substantial confusion and negative perceptions about what 1992 will entail. One U.S. Commerce Department official, Debra Miller, has publicly stated that 1992 will create barriers, not remove them. "EC' 92 is not about deregulation, it's about re-regulation," she said. ${ }^{3}$

\section{A Continuing Process}

In many ways, the unified market that we recognize as EC 1992 has been developing from the start of the European Common Market with the Treaty of Rome in 1957. The formal process underway now was begun with the Single Europe Act of 1986, which was a commitment by the 12 member states to create an area without internal borders for the free movement of goods, persons, capital, and services. The 1986 treaty included a white paper that included 286 pieces of legislation with a schedule for completion of the unified market by the end of 1992 .

\footnotetext{
${ }^{3}$ Travel Management Daily, March 5, 1990.
}

Although it is used as the magical date, 1992 is the symbol for a significant step in a long-term process.

Paolo Cecchini, former deputy director general for internal market and industrial affairs, summarized the EC program as follows:

- extending the area of Community operational responsibility to nearly all the main sectors of legislative and regulatory activities designated to protect relevant public interests; and

- requiring the solution of all political difficulties implied in the transfer of these areas of nearly exclusive national sovereignty to a different, if common legal system.

Cecchini estimates that the economic boost to the $\mathrm{EC}$ resulting from the removal of these barriers will be in excess of $\$ 250$ billion. But the changes will also bring odd wrinkles. A consistent tax policy, for instance, most likely will remove the favorable treatment of capital gains now contained in the West German tax code.

Whatever the effect of the single market, in January 1993, the EC will still consist of 12 widely different countries. Their citizens will continue to speak different languages, guard their national cultures, live according to their old customs, and, it seems, keep their various government policies on tourism.

Worthy pursuit. We believe the EC should pursue a more coherent tourism policy. Europe's tourist trade is the largest in the world, and it has been growing substantially, as has tourism worldwide. But other areas of the world, notably Asia and the Pacific, have been growing faster. In 1960, European destinations represented 72 percent of international arrivals, which numbered 69 million that year. In 1989, the World Tourism Organization recorded 404 million arrivals, but Europe's share had dropped to 62 percent of these travelers. Moreover, Europe's share of tourism receipts dropped from 57 percent in 1960 to 50 percent in $1989 .{ }^{4}$

\footnotetext{
${ }^{4}$ Travel Management Daily, March 30, 1990, quoting WTO Secretary-General Antonio Savignac at the ITIX trade show in Chicago.
} 


\section{Piecemeal Actions}

Tourism seems to be an area where EC activities are not well developed, but the Commission has taken at least some action. Back in 1987, the Commission announced: "For some years now, the Community institutions have become increasingly interested in the problems of tourism." In December 1988, the first formal Tourism Council was convened in the EC. For 1989, the EC allotted tourism a budget of a mere three million European Currency Units (ECU). That figure was zero in $1985 .{ }^{6}$

Admittedly, the EC Commission may believe that there are more pressing issues. Along with the issues raised by the revolution in Eastern Europe, the Commission has placed a high priority on solving obstacles in the agriculture sector and establishing a common economic area. The Commission's activities in these areas will certainly affect tourism.

Of 286 measures contained in the white paper, 76 affect tourism either directly or indirectly. So far, the Commission has eliminated police and tax checks at the borders of member states, increased duty-free allowances, adopted a European passport, and simplified currency restrictions for travelers in most states. Sales transactions will also be facilitated for EC nationals, because European banks are working with the Commission's assistance on interoperative electronic card systems. The Commission has also agreed to hold talks with the U.S. Travel and Tourism Administration on the impact of European unification. The USTTA believes the agreement for talks proves that the EC has "recognized the economic importance of tourism and separated it from other trade matters." Nevertheless, with just two years to go, many barriers to tourism still exist, and the Community needs to establish policies, pass legislation on tax policies and security and health checks at the borders, and harmonize transportation laws and financial issues. Exhibit 1 lists

\footnotetext{
5 The European Community and Tourism, European File, September 1987.

${ }^{6}$ Edward McMillan-Scott, Working Document on the European Year of Tourism 1990, Brussels, December 5, 1989

${ }^{7}$ Travel Management Daily, Feb. 12, 1990.
}

\section{EXHIBIT 1}

\section{Obstacles to be resolved in European tourism}

\section{Obstacles affecting individuals}

- Restrictions by the home country:

- Currency restrictions imposed on residents

- Conditions and procedures for issue of travel documents

- Customs allowances for returning residents

- Restrictions on overseas travel

- Restrictions by the host country:

- Entry visas, identity documents, limitations on duration of stay

- Formalities concerning entry of motor vehicles, pleasure boats, and other craft

- Formalities concerning applicability of drivers license, car insurance, etc.

\section{Obstacles affecting all travel service providers}

- Limitations on foreign investment or equity participation

- Restrictions on the establishment of foreign-owned entities

(e.g., branches and subsidiaries)

- Restrictions on non-national personnel and employment (e.g., visas and work permits)

- Distinction in EC countries between EC and non-EC workers

\section{Obstacles affecting transportation companies particularly}

- Limitations on movements of passengers by foreign airlines or cruise ships

- Requirements for government employees to use national airlines or ferry services

- Limitations on access to reservation systems

\section{Obstacles affecting hotels particularly}

- Restrictions on the import of essential goods

- Discriminatory tax regimes for foreign entrants (including tax holidays not available to nationals)

\section{An overall obstacle}

- Compulsory use of centralized government or municipal organizations or middlemen

Adapted by the authors from: Bernard Ascher, "Obstacles to International Travel and Tourism," Journal of Travel Research, Winter 1984, p.14.

the many obstacles to travel that remain to be resolved at this writing. The following matters (listed on the next page) are some of those that will concern the tourism sector: ${ }^{8}$

\footnotetext{
${ }^{8}$ Largely adapted from: L.J. Lickorish, "European Tourism 1992, The Internal Market," Tourism Management, June 1989.
} 
- The VAT rates in the hotel industry currently vary between 6 percent (Belgium and Greece) and 22 percent (Denmark).

- Visas are still issued by the individual countries, based on bilateral agreements.

- Public transport, notably air and highway, is still strictly controlled, with limits on competition.

- Air transport is still nationally based.

- Greece, Italy, Portugal, and Spain still have limitations imposed on tourists importing or exporting currency.

- Many states maintain limitations on capital and investment. Foreign investors, for instance, are limited to a 25 -percent stake in Spanish charter airlines.

Promotion. In all the work going toward 1992, we could find little impetus for the common promotion of Europe as a destination. The "Tourism: Horizon 1992" conference in 1987 put the following astonishing statement in the record: "Each Community country takes its own measures to promote tourism. The completion of the internal market should not change this in any way." The conference record also said, however, that the member states could benefit from exploiting their share of a common heritage and that the Commission would pursue and multiply its activities through the European Travel Commission (ETC), as well as promoting the European Community through coordinated advertising campaigns. In 1986, the total ETC budget for worldwide activities was $\$ 960,000$, while the individual countries spent $\$ 50$ million in the U.S. alone. At this rate, a coordinated advertising campaign would be modest, indeed.

\section{European Year of Tourism}

Although it may come as a surprise to many Americans, 1990 is the European Year of Tourism (EYT). This project is a promising development for European tourism, since it has been expanded from the original EC members to include the six nations in the European Free-Trade Association (EFTA). The EC's approach to tour-

9 Tourism Policy and International Tourism in OECD Member Countries, OECD, 1989. ism promotion has been more aggressive under the EYT program. Among other things, EY'T is "designed to boost the industry's dynamics in view of the establishment of the single market, to increase awareness of Europe's tourism opportunities, and to bring Europeans still closer to one another." 10 At the inauguration of EYT in Dublin, EC Commissioner for Tourism Antonio Cardoso e Cunha stressed the need for Europe to produce new products, improve existing facilities, and work together to market Europe in North America and Japan.

This promising rhetoric is backed by a budget of only 5.8 million ECU. Moreover, tourism issues are not yet official priorities, and a fully developed tourism policy is needed to integrate tourism with other EC policies. In one case where the Commission has taken action, the airline industry, businesses have responded.

\section{Airline Deregulation}

The Commission has put great efforts into developing general guidelines on competition in this field by agreeing on a framework for the liberalization of civil aviation to be accomplished by January 1, 1993. The airlines have been acrive in positioning themselves for this change. All European airlines, including non-EC carriers, are adjusting to the expected changes by mergers, acquisitions, and other agreements, although attempts at cross-border activities have been largely unsuccessful so far. Air France, for example, is involved in eight agreements, and the efforts of SAS to increase its route system have been widely noted in the media.

Notably, SAS, Swissair, Austrian Airlines, and Finnair have created a "quality alliance." The airlines will design more efficient timetables, develop joint service facilities, and standardize their amenities. As part of the agreement, the four carriers will order up to 239 Airbus and McDonnell Douglas aircraft. ${ }^{11}$

This is not to say that the Commission's work is anywhere near completion. The obstacles to

\footnotetext{
${ }^{10}$ European Year of Tourism Business Plan, First Edition, October 5, 1989.

${ }^{11}$ Travel Management Daily, May 4, 1990, p. 6.
} 
be addressed include the issues of air congestion, cabotage (allowing one nation's carrier to move passengers within another nation), security, grandfather rights, and slot allocation at airports. However, it is important to note that when the Commission finally agreed on a credible policy, the industry was able to act.

National basis. So far, most industries in the tourism sector, except for the major hotel chains, have carried out mergers, acquisitions, and other unifying efforts on a national basis. The reason for this trend is the substantial tax, financial, and legal barriers that hinder or discourage corporations from cross-border expansion. These corporations must break out of their national base to gain competitive advantage in the single European market after 1992. Intensified efforts by the Commission directed at corporate planners could change this pattern.

Outside companies have trouble discerning what the post-1992 pattern will be. A major U.S.-based hotel chain recently studied five European countries as part of its examination of international strategy. The company decided not to consider the implications of 1992 , because they were hard to quantify.

An example of one action the Commission could take was outlined by Horwath $\&$ Horwath in Hotels of the Future, written at the request of the International Hotel Association. H\&H developed a strategy and action plan that listed three "very important factors" under external influences. These factors are the cost of travel, improvements in tourist attractions, and stability. ${ }^{12}$ $\mathrm{H} \& \mathrm{H}$ recommended, among other things, that tourist prices be quoted in a basket of currencies (e.g., the ECU).

\section{The Commission's Role}

Having noted the European Commission's apparent lack of action on tourism issues, we must question whether the Commission is even the proper forum for dealing with these matters. Perhaps it is inappropriate to expect the Commission to develop overall strategies when its primary goal is to remove barriers. Indeed, how can

${ }^{12}$ Horwath \& Horwath, Hotels of the Future, London, 1988. far-reaching supranational regulations be imposed on fundamentally different countries? Our answer is that the Commission, as a central policy authority, should at least develop a strong policy on tourism in the European Community. Without such a policy, the EC may be passing the opportunity to use its combined strength to affect tourism agreements in favor of its member countries.

\section{Even if the European Commission is not the place to resolve all tourism issues, it could at least set overall tourism policies.}

Most observers agree that another European bureaucracy is not the answer to the void in tourism policy. The Commission has already begun to work through the European Travel Commission. Moreover, the basis for economic cooperation on tourism and other issues al ready exists in the Organization for Economic Cooperation and Development (OECD), which includes several nations outside the EC. ${ }^{13}$ One tourism expert, Nils Ragnar Jeansson, sees the OECD as a better alternative for tourism cooperation than the Commission itself. The OECD Tourism Committee has stated that it has an important role to play in the formulation of national and international tourism policies.

\section{EC Potential}

Because Europe is still the largest travel market on the globe, the EC could create or strongly influence international tourism standards by setting its own. Discussing the relationship between the EC and the world travel industry at the Finnish International Travel Fair, Cord D. HansenSturm said, "The EC standards [for package tours

\footnotetext{
${ }^{13}$ The OECD states are Austria, Australia, Belgium, Canada, Denmark, France, Federal Republic of Germany, Finland, Greece, Iceland, Ireland, Italy, Japan, Luxembourg, Netherlands, New Zealand, Norway, Portugal, Spain, Sweden, Switzerland, Turkey, United Kingdom, and United States. Yugoslavia also participates.
} 
and central reservations systems] are likely to become the world standards." The increasing globalization of tourism systems makes it difficult to operate otherwise. U.S. officials see this possibility. The Commerce Department's Debra Miller said the government fears that U.S. carriers will be discriminated against in Europe because the central reservation codes are different between the U.S. and Europe. American Express Travel Related Services is taking an active stance in Europe by giving the EC a total of $\$ 7$ million to support the European Year of Tourism. ${ }^{14}$

This issue is not confined to central reservations systems or package travel, however. The renewed interest in uniform laws on tourism is another area where the EC can influence decisions in favor of its domestic industry. Moreover, non-EC corporations entering the European market would benefit from such broad-based policies, since they would have to adapt to just one set of rules throughout the EC and possibly throughout much of the world.

Contrary to appearances, American travel companies as a whole are disinvesting in Europe. ${ }^{15}$ The EC should be interested in reversing this flow, by taking charge of development and guiding the actors involved. Consistent policies would encourage reinvestment. Investment seems stronger in other areas. One observer reported that in January and February of 1989, "U.S. firms bought into 23 European firms for $\$ 973$ million. ${ }^{16}$ United Parcel Service's purchase of eight delivery companies in the U.K, Belgium, Denmark, and France is an example of this activity.

The European Commission's interest in tourism is fairly new, so the Commission may develop guidelines in time. Moreover, the tourism industry's lobbying power is relatively weak, com-

\footnotetext{
${ }^{14}$ Travel Management Daily, February 5, 1990. American Express is providing $\$ 1$ million in direct financing and $\$ 6$ million in promotional support.

${ }^{15}$ Cord. D. Hansen-Sturm, "The EC and the World Travel Industry," presentation at the Finnish International Travel Fair, January 19, 1989.

${ }^{16}$ Heinz Weihrich, "Europe 1992: What the Future May Hold," Academy of Management Executive, 4, No. 2 (1990), p. 16 .
}

pared to that of the manufacturing industry. The World Travel and Tourism Council, composed of the CEOs of travel companies from around the world, was recently formed to offset this dispersed influence.

Despite the tremendous strides taken with the Common Market, Europe itself has no unifying tradition. While the 50 American states have been a "common market" for more than 200 years, Europe has been nowhere near its present unity since the demise of the Roman Empire, Napoleon notwithstanding. For Americans to understand what the Europeans are in the process of breaking down, they should consider this story, related by Cord Hansen-Sturm. An American asks a Frenchman to explain what policy changes would make Europe more economically competitive. The Frenchman answers that each state in the United States should set up customs facilities at its borders, issue its own currency, and adopt its own language. The existence of these barriers force the EC Commission to move slowly in the area of tourism policies.

\section{Worth the Effort}

As a vital part of the EC economy, tourism is entitled to a more prominent position than it currently holds. The EC may have the considerable advantage of being able to profit from the United States' experience with deregulation, learning from the mistakes that have been made. As Hansen-Sturm pointed out, even if the EC is not about deregulation but liberalization, and setting standards means raising barriers, the EC has everything to gain by an active and conscious approach. It should not be up to each individual company and its hired consultants to investigate and assess the implications of the post-1992 Europe. The EC today has an opportunity to attract corporate investments by presenting a comprehensive policy.

If the European Year of Tourism turns out successfully, it should encourage further joint efforts. The EC will reap obvious benefits in advertising and promotion by sharing costs and expertise, as well as offering a common product.

Pooled ventures in the EC, however, can have even more far-reaching effects. They can create 
advantages for domestic industry, ease foreign investments, create enhanced products, and increase efficiency in infrastructure. The "Chunnel" project, for instance, shows how France and England can gain mutual advantages from joint investment in infrastructure. In contrast, however, look at the lack of synergy resulting from the development of entirely different high-speed trains in France, the United Kingdom, Italy, and Germany.

In this context, the proposed Community competence for commercial aviation and a European Civil Aviation Board (ECAB) is an excellent example of how joint action on a Community-wide level may develop synergy effects. Acting on behalf of EC members (and probably also the EFTA countries), the ECAB would emerge as a powerful negotiating agent with nonEuropean countries. To illustrate what the ECAB could do for Europe, U.S. airlines today have 50 arrival cities in Europe, while European airlines have access to just 20 U.S. cities. Action by an ECAB could shift the weight in this relationship in Europe's favor. The U.S Commerce Department is aware of the potential that the United States will lose landing rights now guaranteed in bilateral agreements, since Europe will be considered a single unit in future negotiations. ${ }^{17}$

\section{Task at Hand}

The European Commission has taken on a tremendous task in setting out to complete the Common Market by the beginning of 1993. So far, however, the tourism industry has not received substantial support, attention, or promotion within the EC. Perhaps the reason for this neglect is that the number of tourist arrivals in Europe has increased over the years. But that increase, as we said earlier, results mostly from the tremendous expansion of international travel. Europe's share of this travel has declined, and we believe that a more concentrated effort would arrest this decline. By fully developing and communicating a comprehensive policy on tourism, the Community would achieve the following goals:

\footnotetext{
17 Travel Management Daily, March 5, 1990.
}

- A structured approach would create credibility for corporate planners in a turbulent industry. Right now, there is no coherent vision of what tourism in Europe will look like after 1992.

- By implementing Community-wide standards, European planners will take the lead in setting international tourism standards. Not only will such standards ease cross-border movement and improve the efficiency of resource use, but EC countries will have a head start on operating within these standards.

- Foreign firms with subsidiaries in the EC will benefit from a more stable environment, and those that are waiting to see what happens will be encouraged to enter the market. By waiting, these firms may miss the ground floor of the largest market available.

Finally, the members of the Community would profit from unified action by economies of scale in promotion.

The tight time schedule for 1992 requires an increased commitment to tourism on the part of the EC. The areas we have touched on in this article scratch the surface of the many issues to be resolved, let alone those yet to be even addressed. To begin with, the European Commission needs to determine its role in tourism. By failing to grasp the full opportunity presented by an active role in the tourism community, the EC will lose the potential gains of joint efforts to generate full economic growth in one of its largest industries.

\section{Pictured from top to bottom}

When this article was first published Peter Ákerhielm, a native of Sweden, was a candidate for the Master of Professional Studies degree at Cornell's School of Hote Administration. Today he is an executive with Present Resor in Bromma, Sweden (peter@ presentresor.info) Chekitan S. Dev, Ph.D., a native of India who studied and worked in France, was an assistant professor and is now a full professor of marketing at Cornell's School of Hotel Administration (csd5@cornell.edu), where Malcolm A. Noden, who was born in England, lived in the Middle East, and owned a travel business in the United States, was a senior lecturer in tourism and now is a visiting lecturer at Cornell (man9@corneil.edu).
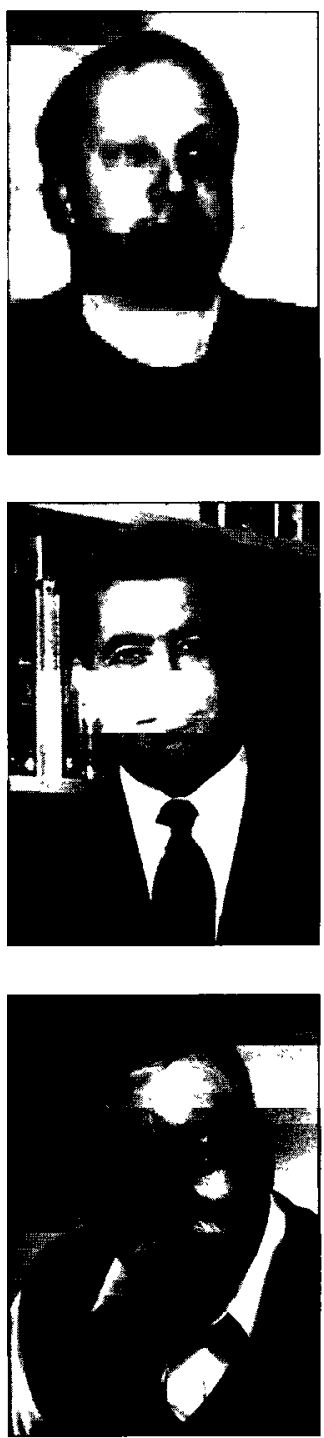